\title{
Re-establishment of Auchenorrhyncha (Hemiptera) assemblages following heath and grassland habitat creation on lowland farmland
}

\author{
Sandra Åhlén Mulio \& Andrew Cherrill*
}

\begin{abstract}
Department of Crop and Environment Sciences, Harper Adams University, Shropshire, TF10 8NB, United Kingdom ( ${ }^{*}$ corresponding author's e-mail: acherrill@harper-adams.ac.uk)
\end{abstract}

Received 12 Aug. 2019, final version received 2 Nov. 2019, accepted 2 Nov. 2019

Mulio, S. Å. \& Cherrill, A. 2020: Re-establishment of Auchenorrhyncha (Hemiptera) assemblages following heath and grassland habitat creation on lowland farmland. - Ann. Zool. Fennici 57: 1-10.

Leafhopper and planthopper (Auchenorryncha) assemblages were investigated at a lowland site in the United Kingdom supporting acidic and mesotrophic grasslands reverting from agricultural use, alongside remnants of semi-natural acidic heath. Further areas of agricultural land had been subject to soil inversion with or without addition of sulphur, heather brash and seed material to establish acidic heath or mesotrophic grassland. Eleven years after work commenced, Auchenorrhyncha assemblages of heath created on former arable land were most closely related to those of remnant semi-natural heath and reversion acidic grasslands. In contrast, an area of heath created on former pasture eight years previously, and at an earlier stage of development, supported an insect assemblage more closely related to those of mesotrophic grasslands. Time since creation, former land use and degree of isolation are identified as potential factors determining the similarity between Auchenorrhyncha assemblages of the remnant and created heaths.

\section{Introduction}

Lowland heath is a plagioclimax habitat that developed on typically acidic infertile soils over many hundreds of years of livestock grazing, burning and turf cutting in the absence of artificial fertilisers (Webb 1998). The UK has an internationally important lowland heath resource, yet much has been lost since the beginning of the 20th century due to land use change, including forestry, housing and the contrasting processes of intensification of agriculture and the abandonment of marginal land (English Nature 2002).
Major impediments to the restoration of degraded heath, and creation of new heath on agricultural land, are elevated $\mathrm{pH}$ and nutrient levels, along with damage to the natural soil profile, presence of 'weeds' and lack of propagules to establish heath vegetation. These issues were identified in pioneering studies of the 1980s and 1990s (Putwain et al. 1982, Clarke 1997, Gilbert \& Anderson 1998). Considerable progress has since been made in the development of techniques to overcome these challenges. Techniques include application of soil amendments (such as elemental sulphur) to reduce $\mathrm{pH}$, turf stripping and deep-ploughing to remove or bury undesir- 
able seeds and nutrient-rich top-soil, continued crop production and harvesting to deplete key nutrients in the soil, and importing seed and plant material to aid recovery of the vegetation (Marrs et al. 1998, Webb 2008, Glen et al. 2017). Most studies have focussed on soil and vegetation to assess the success of interventions. In contrast, few studies have investigated the recovery of invertebrate assemblages following creation of lowland heath, or indeed upland heath and moorland (Webb 2008, but see Littlewood et al. 2006, Forup et al. 2008, Brochard \& Fartmann 2014).

Invertebrates have important functions within ecosystems and are also valuable indicators of the success of habitat creation (Majer et al. 2002). Among the invertebrates, Auchenorrhyncha are a candidate group with which to investigate, and monitor, the success of habitat creation (Biedermann et al. 2005). Auchenorrhyncha are a group encompassing two suborders of Hemiptera (Cicadomorpha and Fulgoromorpha) and known as leafhoppers, planthoppers, froghoppers, treehoppers and cicadas. They are exclusively phytophagous and feed variously on phloem sap, xylem sap and mesophyll cell contents of vascular plants (Nickel 2003). They have been shown to be useful indicators of environmental and botanical change because (a) the group includes species with diets ranging from generalist to highly host specific, (b) community composition responds to management, botanical and abiotic variation, (c) they are numerically abundant in grassland and heath habitats, and (d) taxonomy and sampling methods are wellestablished (Biedermann et al. 2005).

This paper reports on a survey of Auchenorrhyncha at Prees Heath Common Nature Reserve, a lowland site in the English West Midlands, where habitat creation techniques have been applied to former agricultural land since 2006. Management objectives have been to establish both heath and grassland adjacent to surviving remnants of a semi-natural acid grass heath mosaic (Davis et al. 2011). Invertebrates could be expected to rapidly colonise these newly created habitats from the adjacent semi-natural vegetation (Waloff 1973, Morris 1990, Littlewood et al. 2006, 2009). Analysis of the Auchenorrhyncha data is used to test the specific hypothesis that invertebrate assemblages of created heath resemble those of the surviving remnants of semi-natural habitat eleven years after habitat creation began.

\section{Material and methods}

\section{Study site}

Prees Heath Common Nature Reserve $\left(52^{\circ} 55^{\prime} 37^{\prime \prime} \mathrm{N}, \quad 2^{\circ} 39^{\prime} 25^{\prime \prime} \mathrm{W}\right)$ in Shropshire, United Kingdom, is an area of approximately 60 ha (altitude $90 \mathrm{~m}$ a.s.l.) owned and managed by Butterfly Conservation for the nationally threatened silver-studded blue butterfly Plebejus argus (Davis et al. 2011). In 1880, most of the site supported grazed lowland heath, but by 1991 only around 5 ha of heathland vegetation remained and this area, along with 20 ha of semi-natural acidic grassland, was given statutory protection as a Site of Special Scientific Interest (SSSI) (a designation used to protect the UK's most important wildlife sites). The majority of the original heathland had been lost as a result of military training (including an airfield in the 1940s), woodland encroachment and, from the 1960s, intensive cultivation for beans, wheat, potatoes and oilseed rape. After 1991, intensive cultivation continued in some undesignated areas, with addition of chicken manure, until the whole site was purchased by Butterfly Conservation in 2006. Since then, work has been undertaken to create areas of heath and meadow vegetation using combinations of deep ploughing to invert and bury nutrient-rich top-soils, addition of sulphur to reduce soil $\mathrm{pH}$, and addition of seeds, and heather brash. The dominant dwarf shrub at Prees Heath Common is Calluna vulgaris, although management to increase the cover of Erica cinerea (as a butterfly nectar source) is being undertaken using plug plants and seeds.

\section{Survey areas}

Ten areas were selected subjectively to represent five principal vegetation types reflecting different management histories (Fig. 1). The following descriptions of these areas are 
based on the site management plan (Butterfly Conservation 2012), monitoring reports (Ecological Restoration Consultants 2009, 2016), and vegetation surveys conducted in 2007 and 2017 (Whild Associates 2007, McCullagh 2017) which assigned plant communities to the closest vegetation types within the framework of the National Vegetation Classification (NVC) (Rodwell 1991, 1992, 2006). The assignment of areas to NVC types in the paragraphs below should be treated as indicative rather than implying precise matches with the NVC floristic tables (McCullagh 2017). Additional observations on the botanical dominants, the percentage cover of bare ground, dwarf shrub species, and their growth phases, within each sample area were made by the authors in 2018. Botanical nomenclature follows Stace (2019). Heather growth phases follow Gimingham (1972).

Remnant heathland (RH): Two areas supported mosaics of semi-natural acidic grassland (resembling NVC type U1 Festuca ovina-Agrostis capillaris-Rumex acetosella grassland) and dwarf shrub heathland (resembling NVC type H8 Calluna vulgaris-Festuca ovina heath) (Fig. 1). One of these, with an area of approximately 0.5 ha, may represent original heathland that has survived since the 1880s (RH1). The other area was located on the line of the former airfield runway, from which concrete was broken up and removed in the 1970s, and along which semi-natural vegetation subsequently re-established in the absence of agricultural cultivation (RH2). Characteristic species were E. cinerea, C. vulgaris, Luzula campestris, Anthoxanthum odoratum, Lotus corniculatus, Festuca ovina, F. rubra, Carex pilulifera and Avenella flexuosa. In each area, dwarf shrubs represented approximately $25 \%$ of the grass-heath mosaic. Heather was predominantly in the building and mature phases of growth, and bare ground represented approximately $5 \%$ of cover.

CREATEd heATHLAND $(\mathrm{CH})$ : Three areas that had been subject to deep-ploughing, and addition of sulphur, heather brash and seeds were selected (CH1, $\mathrm{CH} 2$ and $\mathrm{CH} 3$, with areas of 6.5 ha, 6.0 ha and 3.0 ha, respectively) (Fig. 1). Two areas had been intensively cultivated, with inputs of chicken manure, until 2006. These areas were deep-ploughed in 2007 with sulphur addition

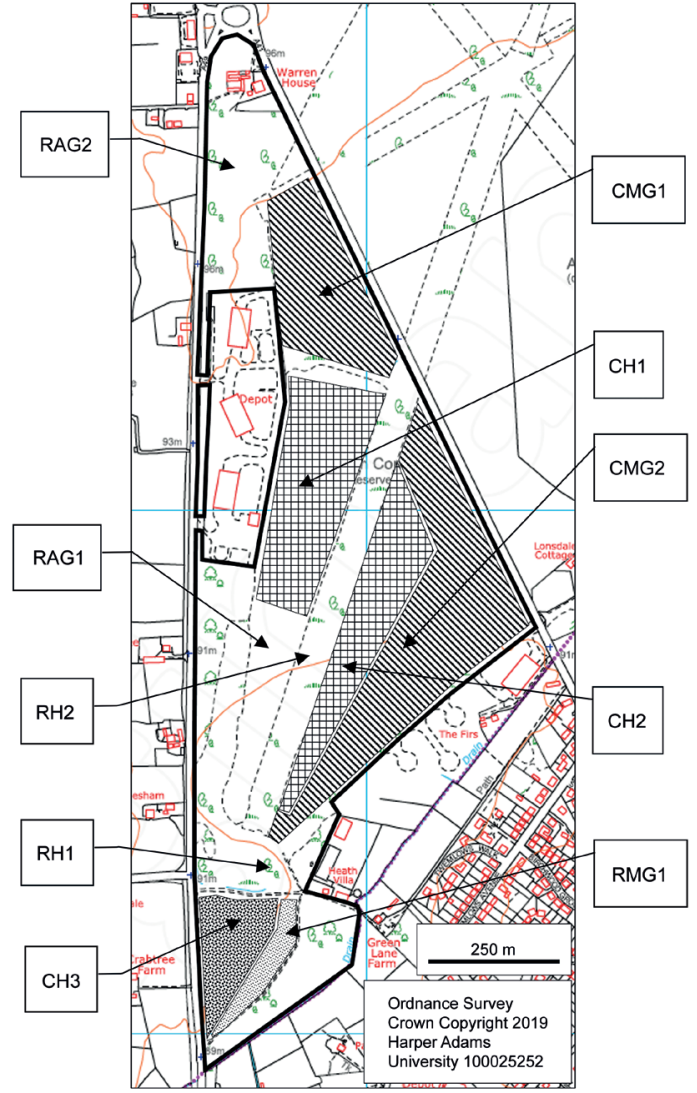

Fig. 1. Prees Heath Common Nature Reserve with the location of sampling areas. Cross-hatched areas are heath created on former arable in 2007 (CH1, CH2); dark stippling is heath created on former pasture in 2010 (CH3); light stippling is mesotrophic grassland reverting from pasture since 2007 (RMG1); diagonal hatching indicates mesotrophic grasslands created on former arable in 2007 (CMG1, CMG2); unshaded land is variously acid grassland reverting from former arable fields since 1991 (RAG1, RAG2), remnants of seminatural grass heath $(\mathrm{RH} 1, \mathrm{RH} 2)$ and small areas of scrub woodland.

in 2007 (CH1) or 2008 (CH2). The former land use of the third area $(\mathrm{CH} 3)$ was grazing pasture (NVC type MG7 Lolium perenne grassland in 2007). This area was subject to deep-ploughing and addition of sulphur in 2010. The vegetation in each field was a mosaic of acid grassland (resembling NVC type U1) with scattered dwarf shrubs heath (resembling NVC type H12 Calluna vulgaris-Vaccinium myrtillus heath). The plant species C. vulgaris, A. flexuosa, Agrostis capillaris and Rumex acetosella were charac- 
teristic of each of the three created heaths. Area $\mathrm{CH} 1$ had a high proportion of heather with 70\% cover (mainly in the building phases). Area $\mathrm{CH} 2$ had approximately $50 \%$ heather cover (mainly in the pioneer and building phases), while area $\mathrm{CH} 3$ had approximately $10 \%$ heather cover (mainly in the pioneer phase). Area $\mathrm{CH} 3$ had approximately $25 \%$ bare ground, which represented $<5 \%$ of cover in areas $\mathrm{CH} 1$ and $\mathrm{CH} 2$.

Created mesotrophic Grassland (CMG): Two areas of mesotrophic grassland resembling NVC type MG5 Cynosurus cristatus-Centaurea nigra grassland were selected (CMG1, CMG2, with areas of 5 ha and 14.6 ha, respectively) (Fig. 1). These created grasslands had been cultivated intensively until 2006 and had received large inputs of fertiliser, including chicken manure. Both were then subjected to deepploughing with addition of hay meadow seed material but not sulphur or heather brash/seeds. Characteristic species were $A$. capillaris, Holcus lanatus, F. rubra, Plantago lanceolata, Trifolium repens, L. corniculatus, Jacobaea vulgaris and Centaurea nigra.

Reversion mesotrophic grassland (RMG): A third mesotrophic grassland (RMG1, with an area of approximately $1.0 \mathrm{ha}$ ) was part of a formerly intensively managed pasture that was classified as NVC type MG7 in 2007, and which has since been undergoing reversion with annual hay cuts. This area was not surveyed by McCullagh (2017), but species occurring with high frequency and cover in 2018 were H. lanatus, P. lanceolata, A. odoratum, Ranunculus repens, Cerastium fontanum and $R$. acetosella suggesting reversion towards MG5. The main part of this field was subjected to measures to create heathland and is included in the study as area CH3 (Fig. 1).

REVERSION ACID GRASSLAND (RAG): Areas RAG1 and RAG2 were cultivated until 1991, but have subsequently been subject to natural rabbit (and occasional livestock) grazing leading to development of semi-natural acidic grasslands resembling NVC type U1 (each with an area of approximately 3.0 ha) (Fig. 1). During cultivation the input of nutrients in both fields is thought to have been less intensive than elsewhere and the grassland has reverted naturally without resort to deep-ploughing, addition of sulphur or seed material. Characteristic species were L. campestris, A. capillaris, H. lanatus, $L$. corniculatus, Achillea millefolium, F. ovina and R. acetosella.

\section{Sampling of Auchenorrhyncha}

In each area, the corners of a $30 \mathrm{~m} \times 30 \mathrm{~m}$ square were marked using biodegradable spray paint. Auchenorrhyncha were sampled from within each square on three occasions in 2018: 18-21 May, 26-27 June, and 30 July-3 August, during fine weather when the vegetation was dry to touch. The summer of 2018 was unusually dry and by early August there was very little green vegetation remaining in any area. Sampling was, therefore, discontinued after the third sample date. On each occasion, four $30 \mathrm{~m}$ long transects were marked within each square. Transects were parallel to the edge of the square and were placed at distances of $6 \mathrm{~m}, 12 \mathrm{~m}, 18 \mathrm{~m}$ and $24 \mathrm{~m}$ from a randomly selected corner. Samples were taken at five intervals along each transect starting at $5 \mathrm{~m}$ from the edge of the square and then with spacing of $5 \mathrm{~m}$. This gave 20 sample points per square on each sampling date (and 60 per square over the whole summer). Positioning of transects and sample points was determined approximately by pacing out distances.

Auchenorrhyncha were sampled using a modified McCulloch GBV 345 garden blo-vac (henceforth G-vac) with the pipe sawn perpendicular to its length to create a flat-ended nozzle with cross-section of $0.01 \mathrm{~m}^{2}$. A nylon bag with $1 \mathrm{~mm}$ mesh was held in place in the nozzle using a rubber band. An open-ended plastic cylinder with cross-section of $0.18 \mathrm{~m}^{2}$ was used to define the sample area at each point and reduce inadvertent suction of specimens from adjacent vegetation (Cherrill 2015). The G-vac nozzle was swept across the surface of the vegetation for $10 \mathrm{~s}$ before being repeatedly raised (to approximately $10 \mathrm{~cm}$ above the vegetation) and then lowered to the ground, while ensuring that the entire area within the cylinder was sampled over the next $50 \mathrm{~s}$. This approach, with a total duration of $60 \mathrm{~s}$ per sample, has been shown to capture virtually all species and individuals of Auchenorrhyncha present within the cylinder 
(Cherrill et al. 2017, 2018). The mesh bag was emptied between each of the 20 samples within a square to prevent clogging of the bag and loss of suction.

Species were identified using Biedermann and Niedringhaus (2009) and Wilson et al. (2015) with examination of male genitalia to confirm determinations. Females of Psammotettix were found in the absence of males and were recorded to genus only. Males of two species of the genus Javesella were recorded, but females of this genus could not be identified to species. Females of this genus were excluded from analyses.

Species with a restricted occurrence in the British Isles were identified from atlases of records at the hectad scale $(10 \mathrm{~km} \times 10 \mathrm{~km}$ grid squares) hosted by the National Biodiversity Network (www.nbn.org.uk) and the Auchenorrhyncha Recording Scheme for Britain and Ireland (www.ledra.co.uk). Species occurring in 100 or fewer hectads are classified as being Nationally Scarce (Wilson et al. 2015).

\section{Data analysis}

Data from different sample points and dates were combined to yield a single species list, with a tally of total number of individuals, for each of the ten sample areas. Ordination was used to summarise the distribution of species and investigate similarities in species composition between sites. Indirect methods, as opposed to a direct ordination method (such as Canonical Correspondence Analysis), were used because the data set was relatively small with limited environmental data (ter Braak \& Prentice 1988). Following recommendations of Lepš and Šmilauer (2003), a preliminary analysis using Correspondence Analysis (CA) was used to determine whether a unimodal or linear method was most appropriate based on the length of the primary axis. It was determined that a unimodal method should be used. Detrended Correspondence Analysis (DCA) (Hill \& Gauch 1980, PISCES Conservation 2014) was applied to remove an 'arch-effect' observed in the preliminary CA, and because the method also performs well with zero-inflated data (ter Braak \& Prentice 1988). The proportion of variation explained by each axis was estimated as a proportion of total inertia derived from Correspondence Analysis as recommended by Økland (1999).

In DCA, it is common practice to downweight scarce species, although concerns have been expressed that the method chosen can influence the results (Poos \& Jackson 2012). In this study, preliminary analyses indicated that the interpretation of the current analysis was robust regardless of the method. For transparency, manual down-weighting was applied by excluding species occurring with fewer than a total of five individuals (when summed across all samples), rather than relying on the downweighting option within the programme.

\section{Results}

In total 1237 adult specimens, including 31 species, were identified (Table 1). Samples collected on the first, second and third dates yielded 249, 612, and 376 specimens respectively. Five of the species are Nationally Scarce: Planaphrodes trifasciata, Delphacinus mesomelas, Mocydiopsis parvicauda, Xanthodelphax flaveola and Xanthodelphax straminea. Of these five species, all but $D$. mesomelas were recorded only from areas of newly created heath (Table 1).

The eigenvalues for the first four axes of the DCA were $0.79,0.31,0.04$ and 0.01 respectively, indicating that $32 \%$ and $13 \%$ of the total variation within the dataset was explained by axes 1 and 2 respectively. The distribution of sites in ordination space broadly reflects the plant communities present, particularly in relation to their position along the major first axis (Fig. 2 and Table 1). Remnant heath areas, and heaths created on former arable, are positioned together at one end of the first axis indicating relative similarity of their Auchenorrhyncha species assemblages. In comparison, mesotrophic grasslands lie at the opposite end of axis 1, while the seminatural acid grasslands occupy an intermediate position. The single heath area $(\mathrm{CH} 3)$ that was created on former pasture lies closer in ordination space to the mesotrophic grasslands than the other heaths. Axis 1 appears, therefore, to represent a gradient from heaths created on ex-arable and remnant heaths, through semi-natural acid 
grasslands to mesotrophic grasslands, and the heath created on ex-pasture (Fig. 2).

A major driver of the positioning of sites along axis 1 is the abundance of Ulopa reticulata. Along with Philaenus spumarius, Dikraneura variata, $P$. trifasciata and D. mesomelas this species has a low score on axis 1 (Fig. 2). Species with low scores on axis 1 are associated with the remnant and created heaths $\mathrm{CH} 1$ and CH2 (Fig. 2 and Table 1). Species with high scores on axis 1, and associated with the created mesotrophic grasslands and $\mathrm{CH} 3$, include Euscelis incisus, Elymana sulphurella, and species of Javesella and Streptanus (Fig. 3 and Table 1). Notably, U. reticulata was not recorded from the younger created heath (site CH3) (Table 1) despite the presence of its host plant $C$. vulgaris.

Positioning of sites along axis 2 appears not to be related to the broad habitat type (Fig. 2). The two sites which were most widely separated on this axis were RMG1 and CH3. These two sites are contiguous on the reserve having been originally part of the same improved pasture (Fig. 1). The cluster of species in the bottom right of the ordination bi-plot show a strong association with site $\mathrm{CH} 3$ (Fig. 3 and Table 1).

Table 1. Numbers of Auchenorrhyncha recorded from each of ten sites at Prees Heath Common. $\mathrm{CH}=\mathrm{created}$ heathland, $\mathrm{RH}=$ remnant heathland, $\mathrm{RAG}=$ reversion acid grassland, $\mathrm{CMG}=$ created mesotrophic grassland $\mathrm{RMG}=$ reversion mesotrophic grassland). Sites and species are ordered according to their scores on the first axis derived from DCA. Species excluded from the DCA are listed in alphabetical order.

\begin{tabular}{|c|c|c|c|c|c|c|c|c|c|c|}
\hline Species & $\mathrm{CH} 1$ & $\mathrm{CH} 2$ & $\mathrm{RH} 1$ & $\mathrm{RH} 2$ & RAG1 & RAG2 & CMG1 & CMG2 & $\mathrm{CH} 3$ & RMG1 \\
\hline Philaenus spumarius & 28 & 0 & 2 & 1 & 0 & 0 & 1 & 0 & 0 & 1 \\
\hline Dikraneura variata & 27 & 1 & 0 & 0 & 0 & 0 & 0 & 0 & 2 & 0 \\
\hline Ulopa reticulata & 278 & 89 & 66 & 29 & 3 & 0 & 0 & 0 & 0 & 0 \\
\hline Planaphrodes trifasciata & 14 & 15 & 0 & 0 & 0 & 0 & 0 & 0 & 0 & 0 \\
\hline Delphacinus mesomelas & 2 & 1 & 1 & 0 & 1 & 0 & 0 & 0 & 0 & 0 \\
\hline Hyledelphax elegantula & 0 & 0 & 6 & 0 & 0 & 0 & 0 & 0 & 0 & 0 \\
\hline Arocephalus punctum & 0 & 0 & 6 & 0 & 0 & 1 & 0 & 0 & 0 & 0 \\
\hline Psammotettix & 2 & 0 & 0 & 2 & 0 & 0 & 0 & 0 & 1 & 0 \\
\hline Neophilaenus exclamationis & 0 & 0 & 21 & 0 & 0 & 59 & 0 & 0 & 0 & 0 \\
\hline Neophilaenus lineatus & 0 & 0 & 10 & 0 & 0 & 1 & 0 & 0 & 1 & 1 \\
\hline Megopthalmus scanicus & 0 & 0 & 9 & 2 & 5 & 5 & 3 & 3 & 0 & 2 \\
\hline Doratura stylata & 0 & 26 & 16 & 18 & 35 & 26 & 21 & 18 & 20 & 2 \\
\hline Eupelix cuspidata & 0 & 0 & 0 & 5 & 2 & 5 & 5 & 1 & 2 & 0 \\
\hline Jassargus pseudocellaris & 0 & 0 & 0 & 0 & 0 & 10 & 0 & 0 & 1 & 4 \\
\hline Euscelis incisus & 1 & 0 & 0 & 1 & 0 & 0 & 10 & 12 & 0 & 12 \\
\hline Anoscopus albifrons & 1 & 4 & 0 & 1 & 0 & 1 & 0 & 1 & 19 & 11 \\
\hline Rhytistylus proceps & 0 & 2 & 2 & 0 & 0 & 3 & 0 & 0 & 29 & 0 \\
\hline Javesella dubia & 0 & 4 & 0 & 0 & 0 & 0 & 0 & 0 & 33 & 1 \\
\hline Mocydiopsis parvicauda & 0 & 1 & 0 & 0 & 0 & 0 & 0 & 0 & 19 & 0 \\
\hline Javesella pellucida & 0 & 0 & 0 & 0 & 0 & 0 & 2 & 1 & 30 & 7 \\
\hline Streptanus sordidus & 0 & 0 & 0 & 0 & 0 & 0 & 0 & 1 & 32 & 0 \\
\hline Elymana sulphurella & 0 & 0 & 0 & 0 & 0 & 0 & 0 & 1 & 9 & 46 \\
\hline $\begin{array}{l}\text { Streptanus marginatus } \\
\text { Species excluded from DCA }\end{array}$ & 0 & 0 & 0 & 0 & 0 & 0 & 0 & 0 & 2 & 6 \\
\hline Aphrodes makarovi & 0 & 0 & 0 & 2 & 1 & 0 & 0 & 0 & 0 & 0 \\
\hline Arthaldeus pascuellus & 0 & 1 & 0 & 0 & 0 & 0 & 0 & 0 & 0 & 0 \\
\hline Cicadula persimilis & 0 & 0 & 0 & 0 & 0 & 0 & 1 & 0 & 0 & 0 \\
\hline Kosswigianella exigua & 0 & 0 & 0 & 0 & 0 & 0 & 0 & 1 & 0 & 0 \\
\hline Muellerianella extrusa & 1 & 0 & 0 & 0 & 0 & 0 & 0 & 0 & 0 & 0 \\
\hline Streptanus aemulans & 0 & 0 & 0 & 0 & 0 & 0 & 0 & 2 & 0 & 0 \\
\hline Xanthodelphax flaveola & 0 & 1 & 0 & 0 & 0 & 0 & 0 & 0 & 0 & 0 \\
\hline Xanthodelphax straminea & 0 & 0 & 0 & 0 & 0 & 0 & 0 & 0 & 1 & 0 \\
\hline Zyginidia scutellaris & 0 & 0 & 2 & 0 & 0 & 0 & 0 & 0 & 0 & 0 \\
\hline Total number of specimens & 354 & 145 & 141 & 61 & 47 & 111 & 43 & 41 & 201 & 93 \\
\hline Number of species & 9 & 11 & 11 & 9 & 6 & 9 & 7 & 10 & 15 & 11 \\
\hline
\end{tabular}




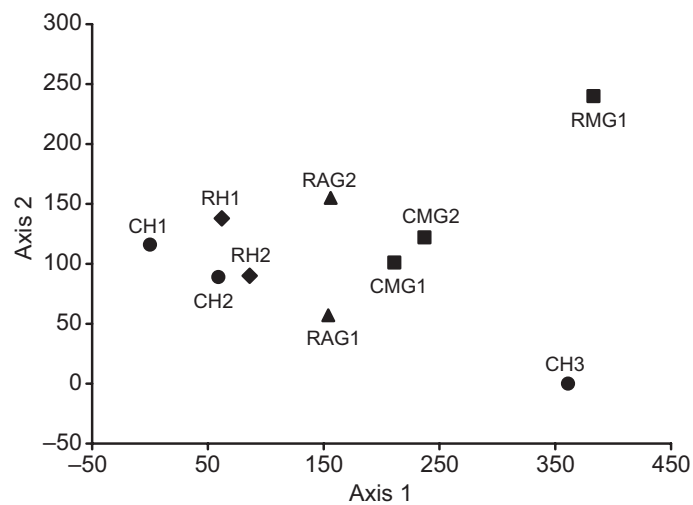

Fig. 2. Detrended Correspondence Analysis (DCA) bi-plot for sample sites based on the assemblages of Auchenorrhyncha present. Labelling of points identifies sites in Fig. 1 and Table 1: $\mathrm{CH}$, created heath; $\mathrm{RH}$, remnant heath; RAG, reversion acid grassland; CMG, created mesotrophic grassland; RMG, reversion mesotrophic grassland.

\section{Discussion}

The months of May, June, and July were unusually warm and dry in the year of this study and by mid-July less than $10 \%$ of grassland and heath vegetation retained its green colouration. Numbers of adult specimens captured in late July-early-August samples would typically equal or exceed those captured in June, but numbers declined. Further sampling might have yielded small numbers of additional species (Cherrill et al. 2017, 2018), but here we focus on the composition of the Auchenorrhyncha assemblages, rather than species richness, and specifically the extent to which assemblages of newly created habitat are similar to those of semi-natural remnants.

Previous studies have shown the composition of Auchenorrhyncha assemblages to reflect mainly the species composition and structure of the vegetation, with soil type, moisture and landscape structure having a lesser influence (Sanderson et al. 1995, Nickel 2003, Biedermann 2005, Nickel \& Achtziger 2005, Helbeing et al. 2017). In this study, variation in vegetation types was summarised using a standard classification system (known as the NVC) (Rodwell 1991, 1992). There can be considerable variation in botanical composition between stands of a single NVC vegetation type, particularly

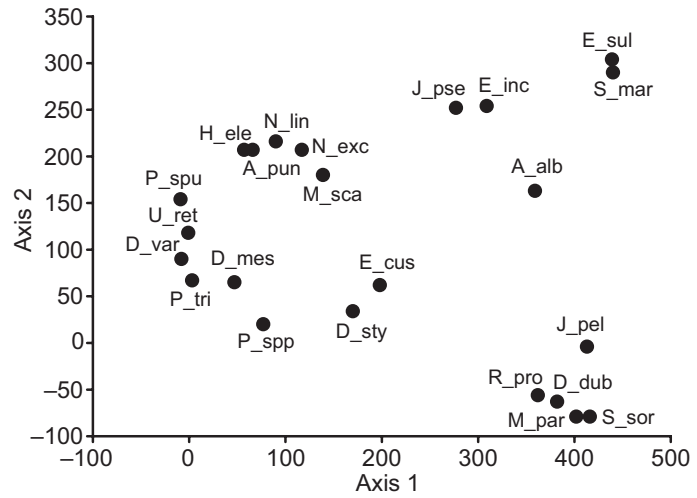

Fig. 3. Detrended Correspondence Analysis (DCA) bi-plot for species of Auchenorrhyncha based on their abundance at the ten sites. Species names are abbreviated from Table 1.

where the vegetation is undergoing rapid change in response to management interventions (Rodwell 2006). Nonetheless, relationships between Auchenorrhyncha assemblages and NVC habitat types with contrasting management histories were evident (Fig. 2). Assemblages in the two heaths created on former arable land $(\mathrm{CH} 1$ and $\mathrm{CH} 2$ ) were similar to those sampled from the remnant heath habitats. Assemblages in the two created heaths included species known to be associated with acidic heathland in England, namely $D$. variata, $U$. reticulata, $P$. trifasciata and D. mesomelas (Le Quesne 1960, 1965, Le Quesne \& Payne 1981) indicating some success in establishing heathland assemblages. Perhaps surprisingly, however, of these four species only $U$. reticulata was also abundant in remnant heath (Table 1), suggesting that the assemblages of remnant heaths may be impoverished or that early and late successional heaths support a different insect fauna.

The third area of created heath $(\mathrm{CH} 3)$ was established on an improved pasture and underwent restoration three years later than those created on arable. The Auchenorrhyncha assemblage in this area was more similar to assemblages of the mesotrophic grasslands than to assemblages of the semi-natural acid grasslands or other heaths (Fig. 2). The site had lower heather cover, a higher proportion of heather in the pioneer stage, and more bare ground compared to the older heaths established on arable. The more recent restoration, and differ- 
ent former land use, of created heath $\mathrm{CH} 3$ may explain the relative affinity of its Auchenorrhyncha assemblage to those of the mesotrophic grasslands and particularly to that of RMG1 (with which it shares a common origin as part of the same improved pasture). It is likely that invertebrates have colonised the new heath from the adjacent mesotrophic grassland (and vice versa); contributing to the relative similarity of their assemblages (Fig. 2). Waloff and Solomon (1973) identified Javesella dubia as an early coloniser of newly created acid grassland, while Javesella pellucida is often the dominant species of improved mesotrophic grassland (Nickel 2003, Cherrill et al. 2017). The assemblages of RMG1 and $\mathrm{CH} 3$ may, therefore, reflect a combination of species of reverting mesotrophic grassland (RMG1) and early successional species of newly created grass heath mosaic $(\mathrm{CH} 3)$. The importance of local dispersal may be magnified because while created heath areas $\mathrm{CH} 1$ and $\mathrm{CH} 2$ are adjacent to semi-natural heath on the former runway, $\mathrm{CH} 3$ is relatively isolated from other heath by woodland to the west, and a farm track bordered by rank grassland and scrub to the north (Fig. 1).

In a review of work on Auchenorrhyncha in fragmented habitats, Biedermann (2002) found that patch occupancy by some species decreased as isolation of patches increased, suggesting that local extinction and re-colonisation are important processes in their distribution. A more recent study showed that species richness of Auchenorrhyncha in habitat patches can be impacted negatively by increasing isolation from other patches of suitable habitat (Rösch et al. 2013). Many species of Auchenorrhyncha have high dispersal ability (Waloff 1973, Morris 1990, Nickel 2003). The role of dispersal in the colonisation of newly created habitat, however, is difficult to determine directly without experimental work or careful monitoring. In an experimental study, Littlewood et al. (2009) found that the colonisation by Hemiptera of heather turves transplanted into grassland declined exponentially with distance from the adjacent heather moorland. Low numbers of $U$. reticulata, a flightless species restricted to feeding on dwarf shrubs (Burrows \& Sutton 2008, Nickel 2003), were recorded on turves up to $40 \mathrm{~m}$ into the grassland after
12 months. These observations are particularly interesting because in the present study U. reticulata was absent from the young heath created on former pasture, but present in large numbers on the older created heaths (Table 1). In the present study, a small number of $U$. reticulata were collected from one of the reversion acid grasslands (RAG1) approximately $40 \mathrm{~m}$ from the nearest heather plants (Table 1 and Fig. 1) confirming their potential to disperse across the site.

The main objective of conservation management at Prees Heath Common is to create new areas of habitat suitable for the nationally threatened silver-studded blue butterfly $P$. argus (Davis et al. 2011). The requirements of the butterfly are well-understood, allowing clear targets for monitoring and management purposes. In contrast, there are no specific management objectives for the Auchenorrhyncha at this site (Butterfly Conservation 2012). In this study, we investigated whether the Auchenorrhyncha assemblages of created heath resemble those of the remnants of semi-natural habitat. It could be anticipated that success in management for both $P$. argus and Auchenorrhyncha will depend on the extent to which new habitat develops to resemble remnant heath. A recent botanical survey of the created heath and grassland, however, concluded that these habitats were still in the early stages of development (McCullagh 2017). Moreover, assessment against benchmarks set by the national statutory conservation agency (Natural England 2009), showed that 'weedy' species of disturbed ground and invading birch saplings were more common than desired in both restored and remnant habitats (McCullagh 2017). It is notable, however, that four Nationally Scarce species of Auchenorrhyncha were restricted to areas of newly created heath, suggesting that early successional heathland habitat may be of value for conservation of these species. In this context it is relevant to question whether the Auchenorrhyncha fauna of the remnant semi-natural heath provides an adequate benchmark against which to judge success. Overall, it is none-the-less encouraging that the Auchenorrhyncha assemblages of heaths created on former arable land resemble those of the remaining fragments of semi-natural heathland, while the acid and mesotrophic grassland 
habitats are developing distinct assemblages to enhance diversity across the reserve. The younger area of heath creation on pasture is at an early stage of development, being characterised by Auchenorrhyncha species of both acidic and mesotrophic grassland. The relative contributions of age since creation, former land use and degree of isolation, to this observation cannot be determined, but subsequent monitoring will reveal how long it takes for species typical of heath to colonise this area.

\section{Acknowledgements}

Thanks are due to Prees Heath Common Nature Reserve site manager Stephen Lewis (Butterfly Conservation) and Natural England for permission to conduct this research, to Georgia Burbridge and Kitty Chin for assistance with field work, to Stephen Lewis, Frances McCullagh (Natural England) and Phil Putwain (Ecological Restoration Consultants) for helpful discussion, and to the two referees for their constructive advice.

\section{References}

Biedermann, R. 2002: Leafhoppers (Hemiptera: Auchenorrhyncha) in fragmented habitats. - Denisia 4: 523-530.

Biedermann, R. \& Niedringhaus, R. 2009: The plant- and leafhoppers of Germany - identification key to all species. - Wissenschaftlich Akademischer Buchvertrieb, Frund, Germany.

Biedermann, R., Achtziger, R., Nickel, H. \& Stewart, A. J. A. 2005: Conservation of grassland leafhoppers: a brief review. - Journal of Insect Conservation 9: 229-243.

Burrows, M. \& Sutton, G. P. 2008: The effect of leg length on jumping performance of short- and long-legged leafhopper insects. - Journal of Experimental Biology 211: 1317-1325.

Butterfly Conservation 2012: Prees Heath Common management plan 2012-2022. - Butterfly Conservation, Wareham, Dorset.

Brochard, F. \& Fartmann, T. 2014: Effects of montane heathland restoration on leafhopper assemblages (Insecta: Auchenorryncha). - Restoration Ecology 22: 749-757.

Cherrill, A. 2015: Suction sampling of grassland invertebrates using the G-vac: quantifying and avoiding peripheral suction effects. - European Journal of Entomology 112: 520-524.

Cherrill, A., Burkmar, R., Quenu, H. \& Zentane, E. 2017: Suction samplers for grassland invertebrates: the species diversity and composition of spider and Auchenorrhyncha assemblages collected using Vortis ${ }^{\mathrm{TM}}$ and G-vac devices. - Bulletin of Insectology 70: 283-290.

Cherrill, A., Burkmar, R., Quenu, H. \& Zentane, E. 2018:
Suction duration and numbers of Araneae and Auchenorrhyncha collected in grassland when using an openended cylinder to define the sample area. - Entomologica Fennica 29: 105-111.

Clarke, C. T. 1997: Role of soils in determining sites for lowland heathland reconstruction in England. - Restoration Ecology 5: 256-264.

Davis, J., Lewis, S. \& Putwain, P. 2011: The re-creation of dry heathland and habitat for a nationally threatened butterfly at Prees Heath Common Reserve, Shropshire. - Aspects of Applied Biology 108: 247-254.

Ecological Restoration Consultants 2009: Report on monitoring the progress of creation of lowland heathland/acid grassland mosaics at Prees Heath Common Reserve for Butterfly Conservation. - Ecological Restoration Consultants, Liverpool.

Ecological Restoration Consultants 2016: Prees Heath Common - status of soils on the reserve and implications for future management. - Report for Butterfly Conservation, Ecological Restoration Consultants, Liverpool.

English Nature 2002: Lowland heathland - a cultural and endangered landscape. - Report IN86, English Nature, Peterborough. [Available at http://publications. naturalengland.org.uk/publication/81012].

Forup, M., Henson, K. S. E., Craze, P. G. \& Memmott, J. 2008: The restoration of ecological interactions: plantpollinator networks on ancient and restored heathlands. - Journal of Applied Ecology 45: 742-752.

Gilbert, O. L. \& Anderson, P. 1998: Habitat creation and repair. - Oxford University Press, Oxford.

Gimingham, C. H. 1972: The ecology of heathlands. Chapman and Hall, London.

Glen, E., Price, E. A., Caporn, S. J. M., Carroll, J. A., Jones, L. M. \& Scott, R. 2017: Evaluation of topsoil inversion in UK habitat creation and restoration schemes. - Restoration Ecology 25: 72-81.

Helbeing, F., Fartmann, T., Loffloer, F. \& Poniatowski, D. 2017: Effects of climate, landscape structure and habitat quality on leafhopper assemblages of acidic grasslands. - Agriculture, Ecosystems and Environment 246: 94-101.

Hill, M. O. \& Gauch, H. G. 1980: Detrended correspondence analysis: an improved ordination technique. - Vegetatio 42: 47-58.

Joint Nature Conservation Committee 2009: Common Standards Monitoring guidance for lowland heathland. Joint Nature Conservation Committee (JNCC), Peterborough.

Le Quesne, W. J. 1960: Hemiptera: Fulgoromorpha. Handbooks for the identification of British insects, vol. 2, part 3. - Royal Entomological Society, London.

Le Quesne, W. J. 1965: Hemiptera: Cicadomorpha. Handbooks for the identification of British insects, vol. 2, part 2a. - Royal Entomological Society, London.

Le Quesne, W. J. \& Payne, K. R. 1981: Cicadellidae (Typhlocybinae) with a checklist of the British Auchenorrhyncha (Hemiptera, Homoptera). Handbooks for the identification of British insects, vol. 2, part 2c. - Royal Entomological Society, London. 
Lepš, J. \& Šmilauer, P. 2003: Multivariate analysis of ecological data using CANOCO. - Cambridge University Press, Cambridge.

Littlewood, N. A., Dennis, P., Pakeman, R. J. \& Woodin, S. J. 2006: Moorland restoration aids reassembly of associated phytophagous insects. - Biological Conservation 132: 395-404.

Littlewood, N. A., Pakeman, R. J. \& Woodin, S. J. 2009: Isolation of habitat patches limits colonisation by moorland Hemiptera. - Journal of Insect Conservation 13: 29-36.

Majer, J. D., Brennan, K. E. C. \& Bisevac, L. 2002: Terrestrial Invertebrates. - In: Perrow, M. R. \& Davy, A. J. (eds.), Handbook of ecological restoration, vol. 1: Principles of restoration: 279-299. Cambridge University Press, Cambridge.

Marrs, R. H., Snow, C. S. R., Owen, K. M., \& Evans, C. E. 1998: Heathland and acid grassland creation on arable soils at Minsmere: identification of potential problems and a test of cropping to impoverish soils. - Biological Conservation 85: 69-82.

McCullagh, F. 2017: Evaluating the progress of habitat restoration at Prees Heath, Shropshire. - M.Sc. thesis, Manchester Metropolitan University.

Morris, M. G. 1990: The Hemiptera of two sown calcareous grasslands. I. Colonisation and early succession. Journal of Applied Ecology 27: 367-378.

Nickel, H. 2003: The leafhoppers and planthoppers of Germany (Hemiptera, Auchenorrhyncha): patterns and strategies in a highly diverse group of phytophagous insects. - Pensoft Series Faunistica 28, Pensoft Publishers, Sofia-Moscow; Goecke \& Evers, Keltern.

Nickel, H. \& Achtziger, R. 2005: Do they ever come back? Responses of leafhoppers to extensification of land use. - Journal of Insect Conservation 9: 319-333.

Økland, R. H. 1999: On the variation explained by ordination and constrained ordination axes. - Journal of Vegetation Science 10: 131-136.

PISCES Conservation. 2014: Community Analysis Package version 5.3.3.472. - PISCES Conservation Ltd, Lymington, UK.

Poos, M. S. \& Jackson, D. A. 2012: Addressing the removal of rare species in multivariate bioassessments: The impact of methodological choices. - Ecological Indicators 18: 82-90.
Putwain, P. D., Gillham, D. A. \& Holliday, R. J. 1982: Restoration of heather moorland and lowland heathland with special reference to pipelines. - Environmental Conservation 9: 225-235.

Rodwell, J. S. 1991: British plant communities, vol. 2: Mires and heaths. - Cambridge University Press, Cambridge.

Rodwell, J. S. 1992: British plant communities, vol. 3: Grasslands and montane communities. - Cambridge University Press, Cambridge.

Rodwell, J. S. 2006: National vegetation classification users' handbook. - Joint Nature Conservation Committee, Peterborough.

Rösch, V., Tscharntke, T., Scherber, C. \& Batáry, P. 2013: Landscape composition, connectivity and fragment size drive effects of grassland fragmentation on insect communities. - Journal of Applied Ecology 50: 387-394.

Sanderson, R. A., Rushton, S. P., Cherrill, A. J. \& Byrne, J. P. 1995: Soil, vegetation and space: an analysis of their effects on the invertebrate communities of a moorland in north-east England. - Journal of Applied Ecology 32: $506-518$.

Stace, C. A. 2019: New flora of the British Isles. - C \& M Floristics, Stowmarket.

ter Braak, C. J. F. \& Prentice, I. C. 1988: A theory of gradient analysis. - Advances in Ecological Research 34: 235-282.

Waloff, N. 1973: Dispersal by flight of leafhoppers (Auchenorrhyncha: Homoptera). - Journal of Applied Ecology 10: 705-730.

Waloff, N. \& Solomon, M. G. 1973: Leafhoppers (Auchenorrhyncha: Homoptera) of acidic grassland. - Journal of Applied Entomology 10: 189-212.

Webb, N. 1998: The traditional management of European habitats. - Journal of Applied Ecology 35: 987-990.

Webb, N. 2008: Atlantic heaths. - In: Perrow, M. R. \& Davy, A. J. (eds.), Handbook of ecological restoration, vol. 2: Restoration in practice: 401-418. Cambridge University Press, Cambridge.

Whild Associates 2007: A botanical survey of Prees Heath Common Reserve - Report for Butterfly Conservation. — Whild Associates, Shropshire.

Wilson, M., Stewart, A. J. A., Biedermann, R., Nickel, H. \& Niedringhaus, R. 2015: The planthoppers and leafhoppers of Britain and Ireland. - Cicadina, Supplement 2: $1-138$ 